\title{
The "Xochitlalli System", an Adoration Ritual to Mother Earth among the Sierra de Zongolica Nahuas in Veracruz, Mexico
}

\author{
Ricardo Alvarez Sevilla ${ }^{*}$, Nelson Eduardo Alvarez Licona², María de la Luz Sevilla González² \\ ${ }^{1}$ Department of Ethnology, National School of Anthropology and History (ENAH), Mexico City, Mexico \\ ${ }^{2}$ Instituto Politécnico Nacional, Postgraduate Studies and Research, Higher School of Medicine, Mexico City, Mexico \\ Email: *ricardo.alvarez.sevilla@hotmail.com
}

How to cite this paper: Sevilla, R.A., Licona, N.E.A. and de la Luz Sevilla González, M. (2020). The "Xochitlalli System", an Adoration Ritual to Mother Earth among the Sierra de Zongolica Nahuas in Veracruz, Mexico. Advances in Anthropology, $10,33-47$.

https://doi.org/10.4236/aa.2020.101003

Received: September 10, 2019

Accepted: December 28, 2019

Published: December 31, 2019

Copyright $\odot 2020$ by author(s) and Scientific Research Publishing Inc. This work is licensed under the Creative Commons Attribution International License (CC BY 4.0).

http://creativecommons.org/licenses/by/4.0/

\section{(c) (i) Open Access}

\section{Abstract}

The Nahua population from the "Sierra Zongolica" in Veracruz, Mexico, has built a type of communication with a supra-human deity with capacities, which from its majesty can give, remove, help, harm, create or destroy, the Mother Earth entity to whom it's spoken through the worship ritual known as Xochitlalli (from xochitl "flower" and tlalli "earth"). Xochitlalli is a ritual practice that involves a series of steps through which a space is sacralized to establish communication between the man and the earth goddess, and although no Xochitlalli is equal to another, all meet a series of regular events: 1) Demarcation of place and space; 2) Petition, gratitude and apologies; 3) Dialogue from prayers and to give drinks and food to Mother Earth. In this context the research question was: what is the explanatory mechanism that allows us to understand the validity of the Xochitlalli ritual practice among the Nahua communities from the Zongolica mountain range in Veracruz, Mexico? The phenomenon has been observed as a system, in which the Xochitlalli System, understood as a generative mechanism, is distinguished invariable elements that give organization and class identity to it, based on the cultural references that the Nahuas from the montauin range have. The invariable elements present in all the rituals are: to give food and, in the case of drinks, sharing them with the deity; performing the Xochitlalli, using ritual objects; and offering apologies, thanks and petitions through prayers in the Nahuatl language.
\end{abstract}

\section{Keywords}

Nahua Communities from Zongolica, Ritual Xochitlalli, Food, Ritual Objects, Prayers in Nahuatl 


\section{Introduction}

The relationship between men and deities in history and societies, has been mediated by a form of dialogue, which is not the same that people use among themselves; it is a particular dialogue, a dialogue structured by different patterns that condition the intentionality of the communicative act, a necessary condition that considers the origin and essential structure of the deity as a supra-human being with infinite and unattainable capacities and of man as a mortal who transits in a finite time, that is sponsored by other being what from its majesty can give or take away, help or harm, create or destroy, Mother Earth.

This form of interaction, from the logic of the social actors, is constituted by the basic conditioning factors so that the Nahuas from the Sierra de Zongolica can communicate, according to fundamental elements in the construction of identity in these communities, being Mother Earth one of the most representative and ancient deities from the Mesoamerican cultural pantheon. Based on data provided by INEGI, the company that today lives in the Zongolica mountain range, is mostly composed of: 1) Nahua-speaking speakers who were self-ascribed as indigenous and corresponding to $71.59 \%$ of the population; 2) Mestizos who no longer share many of the cultural references with the Nahua groups and that corresponds to a $28.4 \%$ of the population; 3 ) people who come and go, who enter and leave the community but who do not reside there.

The society that today lives in the Sierra de Zongolica, is composed mostly of: 1) Nahua language speakers who were self-identify as indigenous; 2) "Mestizos" who no longer share many of the cultural references with the Nahua groups and 3) People who come and go, who enter and leave the community but who do not reside there, such as health workers, social workers, teachers, merchants, builders or evangelizing groups that have had an influence on the Nahua communities of the sierra. In this mosaic of cultures, living together in the XXI century effervescence in the postmodern context, we observed among the Nahuas from the Sierra de Zongolica a religious system that constructs the idea of various divinities that are necessary for the creation and functioning of society: God, Christ, the virgin and other saints that are part of the Catholic ideology and also Mother Earth, air, rain and other natural entities that are divinized.

The figure of Christ has been strongly implanted in the Nahua cultural pantheon from the Sierra de Zongolica. His life, teachings, death and resurrection are phenomenon known, accepted and worshiped; inside temples and xochitlaleras houses, it is common to find altars to the virgin of Guadalupe, images of Jesus Christ and other saints; these catholic canon figures are respected and worshiped. While this contact or approach to Western culture is clear, this has not suppressed or diminished the semiotic wealth of the Nahua worldview; on the contrary we observe a phenomenon in the expansion of the cultural pantheon of the Nahuas of the Sierra de Zongolica where God, his son Christ, the Virgin of Guadalupe and the saints who accompany them, have been adopted, incorporated, re-signified and used as other divine entities to which they are also worshiped, but which do not overlap, are not syncretized, are not masked, or 
transform into the Mother Earth deity that is identified among the Nahua communities from the Sierra de Zongolica as a separate deity, with its own functions, attributions, characteristics and concrete forms to enter into interaction. Therefore the Xochitlalli is the adequate form to establish communication with Mother Earth.

In the Sierra de Zongolica the catholic god and the Mother Earth deity, are two different deities, with different meaning, denomination, ritual and language. This rich cultural pantheon held by the Nahua from the Sierra de Zongolica, is possible, in great part, thanks to the cultural heritage of the pre-Hispanic era, this heritage makes it possible for the acceptance of various divinities in the religious practices carried out by them without coming into conflict between the individuals who participate in them. The Catholic God, Father God, appears in this religious system not as the only and supreme, but as another of the deities that make up the divine universe that the Nahua from Zongolica have built, which does not relegate it to a second place in a matter of hierarchy, is another deity who is worshiped differently and in a different context, Father God is spoken in the temple, at the houese's altar or before sleeping when praying by the bed, but to Mother Earth is spoken to with Xochitlalli

Theoretical framework: The theories from which the observation of the Xochitlalli ritual as a system is orchestrated, allows to observe the phenomenon from the social logic of the actors based on the interactions of the elements distinguished by the observer, so that the coherence of the system corresponds to the practice of the subjects, based on field work. The realization of this ritual practice is a voluntary decision, because there are no imperative conditions to be made, so that the observation regarding the choice of Xochitlalli as the indicated procedure for the resolution of certain problems, is addressed from the Theory of Rational Choice (Di Castro, 2002). The Xochitlalli ritual act is framed within an ancient human practice of earth worship, for which we have used the historical and comparative references of Eliade $(1991,2008)$. To address the sensibly significant phenomenon of the hierophanic experience, the categories are used: Misterium tremendum, Feeling of creature and Tremor proposed by Otto Rudolf (2007). Starting from the fact that reality is a construction and that subjects practice occurs in being, where social referents acquire concreteness in the constructions of reality of the subjects, recourse is made to the theoretical proposals of Dumont (1987) and Alvarez (2012). With these theories a logical proposal is constructed and in congruence with the networks of meaning of the social actors, to propose a system of relations between the elements distinguished from the theory of systems, which is based on the works of Maturana (2014) and De la Reza (2010).

The Xochitlalli is a ritual practice that involves a series of steps through which a space is sacralized for communication between man and the earth goddess. No Xochitlalli is the same as another, all are different and original even though they fulfill a series of events or steps in which regularities are found: 1) Demarcation of place and space, 2) Request, appreciation or apology, 3) Dialogue from pray- 
ing and pouring and/or drinking liquids to the earth.

1) The place and space: The ritual begins with the demarcation of space, no more than $2 \mathrm{~m} \times 2 \mathrm{~m}$; the place was chosen according to the request or thanks to the earth goddess; this ritual act is performed in a sick person's house, in the land of sowing, in a productive process, next to a construction, inside a corral. The demarcation of space is done with seasonal flower petals: roses, daisies, cempaxúchitl. In this place a series of objects and foods offered to Mother Earth are deposited: beer, coffee, brandy, tobacco, incense with copal, xochimanale (bouquets of flowers wrapped in orange leaves) and a cross covered also with flowers.

2) Petition, appreciation or apology: In this sacralized space, humbly and kneeling the xochitlalera prays in Nahuatl, making the request, thanks and apology for the offense that men constantly do to dispose of the goods that Mother Earth gives.

3) Dialogue from prayer in Nahuatl and give food to Mother Earth pouring and drinking liquids. In this ritual act the participation of the officiant (xochitlalera) and the applicant(s) is observed. The drinks are arranged in a jug, a part is offered to the Mother Earth (dropping a portion of liquid) and then the applicant and the xochitlalera drinks, on the sidelines but participating in the ritual act always find relatives or close people.

Being the elements that are operationalized in the relational logic of asking for forgiveness, asking permission and thanking, that comes from understanding the communication between man and Mother Earth, not between equals or similar where exchange relationships can be built, if not in an asymmetrical relationship between man and the goddess Mother Earth.

Explanatory mechanism proposed for the explanation of the phenomenon. The observation of the Xochitlalli phenomenon as a Social System, where the behavior of the social actors structures a network of interactions that generates the Xochitlalli ritual that characterizes it, thus being a particular system that is defined by its organization, where the referred elements are invariable, even when the structure of the system changes maintains its class identity, Xochitlalli.

"Whenever the members of a group of living beings constitute with their behavior a network of interactions that operates for them as a media in which they are realized as living beings and in which they, therefore, conserve their organization and adaptation and there is a contingent coderiva to their participation in this network of interactions, we have a social system... This kind of systems is the inevitable result of the recurrent interactions that occur between living beings and whenever they occur with any permanence, will give this type of system" (Maturana, 2014: p. 26).

The corpus of the research, has been constituted from the experience obtained in 10 years of continuous field work, with an average of 3 annual stays for periods of 15 days each, which began in 2005 and continues today, which is equivalent to a field work of approximately 1 year 3 months of stay in the Nahua com- 
munities of the Sierra de Zongolica, where various intervention projects have been carried out: socio-educational, health and productive projects in these communities, at the same time that the registration of several ceremonies of Xochitlalli rituals was made. The collaboration and implementation of socio-educational and health programs in the Sierra de Zongolica, has allowed greater contact and closeness with different groups of the community of midwives and traditional doctors, groups of families, seniors, XEZON indigenous radio workers. These community interventions made it possible to integrate with the community and create links, including kinship, such as godfathering, which made it even easier to observe certain types of rituals that only take place within families. Being invited and participating in rituals as active members of the community, strengthening bonds of trust, which was further increased by the study and management of the Nahuatl language, by building collective identity links with different groups. Having a command of the language, in this Nahuatl case, allows the social sciences professional to rely on information, not depending on the translator, who filters interpreting linguistic phenomena.

Research question: What is the explanatory mechanism that allows to understand the validity of the Xochitlalli ritual practice observed as a system among the Nahua communities from the Sierra de Zongolica in Veracruz? Being the Objectives: 1) Identify the reasons why the choice of the Xochitlalli as a habitual procedure to solve the events of everyday life. 2) Explain why this practice is valid today? 3) To establish how is it that the practice of Xochitlalli is so widespread and incorporated into the logic of the behavior of the Nahuas of the sierra, over time. Research techniques: The corpus of the research was built with field notebooks raised in the rooms referred to the registration of the Xochitlalli. A photographic record of Xochitlalli's practices was made during the 10 years we have been in the Sierra de Zongolica, Veracruz. A video file has been generated regarding the preparations and the realization of the Xochitlalli ritual and other ceremonies related to this ritual plus records of community interventions that we have made and other community parties. These audiovisual materials have also been used in the analysis and contextualization for ethnographic descriptions. There were more than 30 open semi-directed interviews to ritual officiants and to those who request it, identifying the motives and requests that they made to Mother Earth, which were transcribed and analyzed. Audio-recorded prayers were written in the Nahuatl language that was directed towards Mother Earth in the Xochitlalli ceremony, which was translated from Nahuatl into Spanish for the analysis of its content.

Spatial location and habitat characteristics: The Sierra de Zongolica with an area of 347 square kilometers, is located in the middle mountainous area of the state of Veracruz, Mexico. It limits with the states of Oaxaca and Puebla. And although the name corresponds to a perfectly located township, this whole mountain range is known as Sierra de Zongolica, including other municipalities such as: Atlahuilco, Astacinga, Mixtla de Altamirano, Reyes, Tehuipango, Tequila, Texhuacan, Tezonapa and Xoxocotla. The majorethnic group is Nahua (Figure 1). 


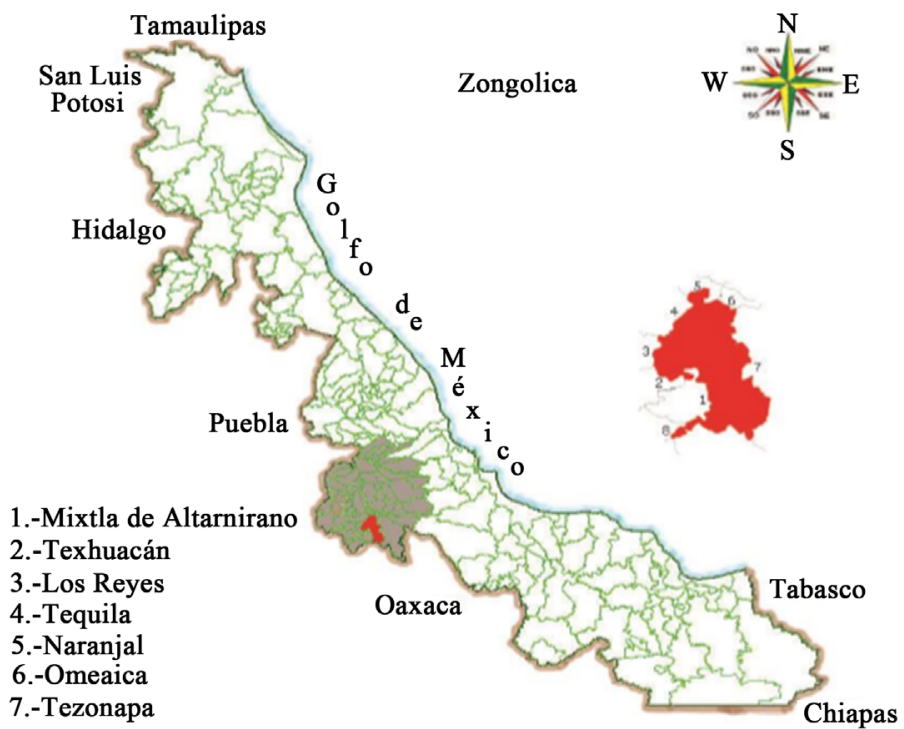

UBICACIÓN

Entre los paralelos $18^{\circ} 32^{\prime}$ y $18^{\circ} 47^{\prime}$ de latitud norte; los meridianos $96^{\circ} 50^{\prime}$ y $97^{\circ} 02^{\prime}$ de longitud oeste; altitud entre 100 y $2000 \mathrm{~m}$

Figure 1. Taken from the national institute of statistics and geography (INEGI) in 2013. México.

The town of Zongolica headboard of the municipality, is located 38 kilometers from the city of Orizaba, however the winding roads make it difficult for people to enter and leave, turning these 38 kilometers in rainy seasons and hazy winter days, into a few hours of traveling by car, on a difficult road that has no alternatives but the few options that the steep mountain range gives, which forces a necessarily slow transit, along a narrow-closed curves road between high mountains on one side and deep precipices in the other, almost as reaching the clouds, which in summer become thick fog and torrential downpours that make the path even more difficult. This mountain range is one of the most rugged topography of the country, with heights ranging from $200 \mathrm{~m}$. at $3000 \mathrm{~m}$. above sea level. The Sierra de Zongolica has been divided into three zones: cold, warm and hot, which is manifested in the different types of agricultural products found in this mountain range, with coffee being one of the main agricultural resources of the region; the altitude also results in the difficult climatic conditions that have to endure, especially those who live in cold areas, where respiratory tract disease are the most frequent, being tuberculosis the one with the higher incidence. In these geographical conditions, the place is cataloged with rates of high Social Recession and Extreme Poverty (CONEVAL, 2015).

Results: Among the Nahuas from the Sierra de Zongolica in Veracruz, Mexico, the practice of Xochitlalli ritual, from Xochitl (flower) and tlalli (earth), it's found as an event that does not need a date in the calendar or an excessive planning for its realization, this ritual practice is integrated into their daily life in such a way that is part of the common sense of the Nahuas who inhabit this mountain range, when speaking of common sense we refer to "a relatively orga- 
nized set of speculative thought... its principles are immediate liberations of the experience and not deliberate reflections on this... common sense is based precisely on the claim that in reality there is no other theory than that of life itself. The world is its authority" (Geertz, 1994: p. 95). The practice of Xochitlalli, being integrated to the common sense of the inhabitants of the Zongolica mountain range, is a resource that is used regularly to solve the multiple problems faced by the Nahuas in the area. The use of the ritual Xochitlalli as a way to face the situations of everyday life, derives from the rational choice of subjects, who decide the best way to solve their problems, the Rational Choice (Di Castro, 2002: pp. 45-82) as a theory explanatory, provides conditional imperatives on the media to achieve certain purpose, it is an intentional action that is characterized by its relationship with the future. Man is also an economic subject constituted by a set of beliefs, desires and preferences, who has a set of possible strategies, given certain restrictions. Rationality involves choosing the strategy that best satisfies the agent's wishes, taking into account the beliefs supported by the evidence, which makes the choice rational.

In this way the Nahuas from the Sierra de Zongolica decide from a rational choice, to perform the ritual Xochitlalli, because it corresponds to the elements of rationality with which they construct their reality. Based on the experience in the field, we have found that the Xochitlalli is a standard practice in the life of the Nahuas of the Sierra de Zongolica and each xochitlalera (who officiates the Xochitlalli) and people who request the realization of this, perform the practice of Xochitlalli according to its knowledge and dispositions, understanding by dispositions the type of resources and the accessibility to these, with which the ceremony is performed, thus the relationship between desires, beliefs and evidences, is based on the experience of the daily life of the Nahuas who have learned since childhood through traditional forms, the construction of their memory, the consequences of the realization or not of the ritual of adoration to Mother Earth, Xochitlalli (Figure 2).

It is illustrative to retake the case of Xochitlalli made to Mrs. Gerónima, since it is necessary to establish a series of facts that will allow us to understand the importance of this Xochitlalli. In the year 2011 Mrs. Gerónima (midwife, traditional doctor and xochitlalera of the region), who, at her 70 years, has already helped to birth hundreds of Nahuas by the Sierra de Zongolica, suffered from an illness in her right foot caused by a chronic ulcer wound, due in part to her diabetic condition, this injury has caused her much pain and immobility, although she had already seen a doctor in hospital coverage, her health and mood did not improve, in addition to increase her physical weakness bad condition. Mrs. Gerónima situation got worsed due to a terrible event, one of her children died in a car accident on one of the dangerous roads of the Sierra de Zongolica. Upon hearing the news and seeing how Mrs. Gerónima's health worsened, we asked Mrs. Soledad (Mrs. Gerónima's daughter), if they had done some Xochitlalli to heal her mother? and she told us that they had not been able to do it, due to lack of money, since the tragedy had happened recently. We offered to organize one, 


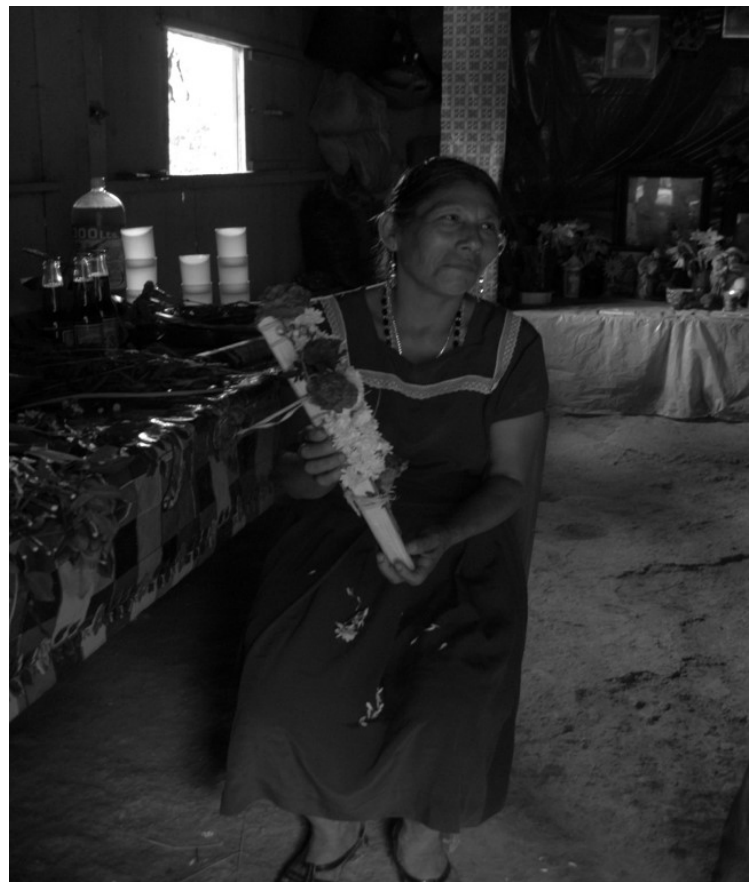

Figure 2. Taken from Ricardo Alvarez Sevilla, Escuela Nacional de Antropología e Historia (ENAH). Cristina carrying wooden cross covered with flowers.

ask a midwife for help, buy the necessary objects, set a date and have Geronima's authorization for that purpose. So and on the recommendation of our friend Cira Quechulpa, a journalist and host of Radio XEZON (which is a community radio), she recommended Mrs. Cristina, xochitlalera for many years, a friend of Mrs. Gerónima and founder of the oldest group of midwives of Zongolica. The news of doing Xochitlalli made Mrs. Gerónima and her family very happy, so we started immediately the preparations.

The Xochitlalli took place in Mrs. Gerónima's, it was a very special ceremony and one of the most touching Xochitlalli that has been a registrated due to an intense effort in petition, consisting of the help from Mother Earth so Mrs. Gerónima's spirit will return to her, as she had been at the scene of her son's accident when she went to visit the site of the accident. The xochitlalera Cristina, said that was the reason why she was so sick and sad.

Three months later we returned to Mrs. Gerónima's house, her foot had healed, her apathy had disappeared, her vitality and good humor came back and she was already walking down the mountain, talking to her and her family, however, no surprise reaction was observed about the improvement of her health and mood, for them it was expected, it was the expected response of Xochitlalli's search, the situation of faith in her beliefs, she was not surprised (Figure 3).

If Mrs. Gerónima was healed by Mother Earth and if it can be attributed to the "symbolic efficacy" (Lévi-Strauss, 1992: pp. 211-227) what originated a change in the state of health of Mrs. Gerónima, it is something irrelevant. The important thing is that for the xochitlalera Cristina, Mrs. Gerónima and her family, just to 


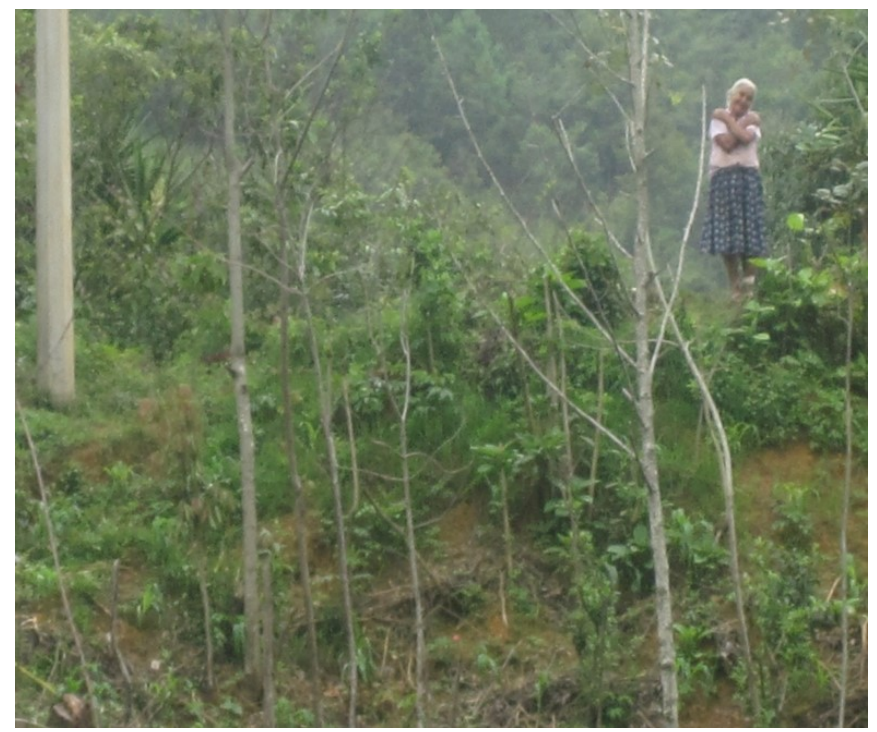

Figure 3. Taken from Ricardo Alvarez Sevilla. Escuela Nacional de Antropología e Historia. (ENAH). "Gratitude Gerónima, midwife traditional doctor and xochitlalera” of Zongolica Veracruz.

be one more evidence of the power of Mother Earth, the fact that she reaffirms her beliefs in the telephone networks, helping to satisfy her wishes for health, which is why it is rational decision to make a Xochitlalli, in situations of need, for those who live in the Sierra de Zongolica and who have had a life full of evidence to believe in the effectiveness of these practices on Mother Earth.

"The sociologist cannot dedicate himself to verify or falsify scientifically the beliefs of the actors. The effectiveness of ideas, beliefs, consciences does not depend on their truth or falsity, but on their ability to determine behavior and, therefore, their degree of social evidence; that is, that effectiveness depends on power, on the capacity to impose as social truth a certain way of defining reality, independently of its truth or falsity" (Pérez Argote, 1986: p. 86) (Figure 4).

The Xochitlalli System, as an explanatory mechanism, emerges from the Xochitalli ritual practice observed as a composite unit, in which is distinguished invariable elements that give organization and class identity to the system, based on the cultural references that the Nahuas have. By making a series of observations in the field made of various registered Xochitlalli, a series of invariable elements could be identified in all the rituals, which give class identity to the Xochitlalli System, based on the logic of the social actors.

The multiplicity of forms and reasons that lead the Nahuas from the Sierra de Zongolica to perform these ritual practices, confuses the researcher at first, since Xochitlalli ceremonies are held so that the predators of the field do not take the animals from corral like the chickens, to cure a varicose ulcer, so that a bridge does not come down, so that in the work there are no envies, so that the child is returned to the spirit that separated him because of a fright, so that it rains, so that it stops raining, to build a house, a corral or so that the sowing goes well, among many other reasons. We observe that some use holy water, others dance 


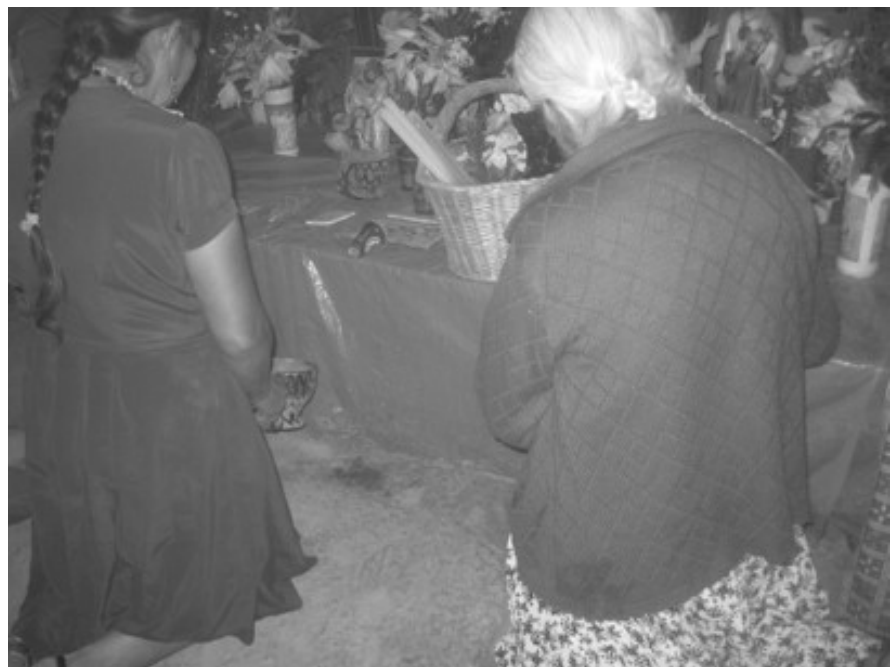

Figure 4. Taken from Ricardo Alvarez Sevilla, Escuela nacional de Antropología e Historia (ENAH). "Xochitalli ritual practice".

for Mother Earth, bury a living animal (chickens or turkeys, usually). This is how it was possible to recognize a series of constitutive elements of the ritual present in all the Xochitlalli, which, based on the logic of the social actors, are indispensable for its realization, therefore they constitute the organization of the Xochitlalli phenomenon and without which it is spoken of another social phenomenon and not of a Xochitlalli, in more than one sense, the understanding of a system, consists of the recognition of the forms, variations and particular characteristics of its relations. These are represented as a set of forces (or variety) that have registered the parameters and dynamics of system integration (De la Reza, 2010: p. 105). One afternoon with Mrs. Julia, who is a traditional doctor and a person of great respect in the community of Tepecuitlapa located in one of the highest areas of the Sierra de Zongolica, sitting on the ground outside her wooden house, while we were removing the beans of her pods, talking about the family, she says:

- Mrs. Julia: "Well my daughter-in-law it's about to turn 40 days since her son was born".

- Ricardo: Oh, good it's been 40 days; aren't you going to perform Xochitlalli for her?

- Doña Julia: “Well, I don't think so, I've been very busy and got no money. I'm only going into go to her house, light a candle to Mother Earth, thank her y take her some coffee, but no Xochitlalli".

Mrs. Julia, like the rest of nahuas that perform Xochitlalli, is aware that this grattitude given to; Mother Earth, didn't have all the elements needed for a Xochitlalli, there wasn't any cross, incense, flower petals, brandy, tobacco or coffee.

Xochitlalli System's constitutive elements: "Modeling a complex system wich first implies defining a set of relationships, facts, elements, subsystems, levels, operations and externally delimited variables and whose components acquire meaning by their ability to structure the whole" (De la Reza, 2010: p. 125). Based 
on the analysis of the elements recorded in the fieldwork and the analysis of the interviews conducted, we identified the constituent elements of the Xochitlalli System, according to the logic of the subjects, which give them organization and meaning to their class identity: 1) Food; 2) Ritual Objects; 3) Prayers in Nahuatl.

1) Food is essential in the ritual act however this can be in the form of an alcoholic beverage (doesn't matter if it's pulque, aguardiente, tequila or beer), coffee (essential) or prepared food such as enchiladas, beans or quelites.

2) Ritual objects, where the cross covered with flowers is always present in the ceremonies but the size and decoration is the decision of the xochitlalera, the waxes are a fundamental part of the Xochitlalli System, however sometimes the xochitlaleras prefer 4 white and 4 yellow, other 4 white and two yellow, sometimes the color is not important to them while they are present.

3) The prayers, which are the fundamental axis of the Xochitlalli, are fundamental in the logical coherence of the system, they can be very different and for very different reasons; its duration can be $45 \mathrm{~min}$ to an hour, although we have seen some of more than 3 hours, but in all we ask for permission, we ask for forgiveness and it is appreciated, and although in some occasions we pray in Spanish, almost the entire prayer. It is in Nahuatl.

The relationship between food, ritual objects and prayers in Nahuatl, gain operational coherence by entering into a relational logic that gives them meaning, we propose that the relationship between the elements of the Xochitlalli System is based on asking for forgiveness, asking for permission and thanking mother Earth. This sense of the communication of the social actors with the deity, has to do with an intention of respect, admiration, fear and hope; communication that can't occur in any other way against the omnipotent and omnipresence of Mother Earth, understood as a deity for the Nahuas of the Sierra de Zongolica.

But, what is the common thread that allows us to explain the coexistence of these relational senses between the elements that make up the Xochitlalli System? Rudolf Otto (2007) refers to a sensation that helps us explain that peculiar moment in which man finds himself involved in the experience of the divine. This experience is elucidated through theoretical categories, such as: Feeling of Creature, Mystery Tremendum and tremor. When we enter the field experience of the divine, we must go slowly trying to apprehend this experience through theoretical categories, due to the difficulty of understanding them from the sensations, for this reason we highlight and use the sensibly significant categories of Otto (2007) since (from our perspective) with these, allows the reader to situate himself in the field of sensations, and from there to help us explain certain particularities of the hierophanic experience that happens in the ritual act, that implements a perspective of seeing that allows to represent coherently some sensitive phenomena of the Xochitlalli ritual.

For Otto (2007) the sentiment of the creature refers to that sensation where man sinks into himself in front of that being that can do everything, that has everything, that is everywhere and over all creatures; be from where all things come, what corresponds to the phenomenological moment or emic. It is the $\mathrm{Nu}$ - 
men, defined by Otto as that which moves the mind with this or that tonality, it is the presence of the deity, it is to be before a god, before the supreme. But what characteristics distinguish that experience? The category "Tremor" proposed by Otto facilitates the approach to this hierophanic phenomenon, Otto uses this category to refer to that sense of fear of the absolute power of a deity, but that does not correspond to fear itself, that is, in the recognition of the Theophany, through the hierophanic experience, the feeling of vulnerability and dependence cannot be separated from fear towards the same entity, however, it is not a fear in terms of demonic terror, it is a fear in terms of humility before the majesty of the theophany, majesty that does not cease to be imposing and definitive in the perception of the subjects and that is detached from them.

It is in these living experiences that the sensation of the Mysterium Tremendum becomes palpable, as Otto describes it:

"It can be felt in various ways, it can penetrate with gentle flow in the mind, in the form of a calm feeling of absorbed devotion; it can pass like a fluid current that lasts some time and then there, it trembles and in the end it goes out, letting the spirit revert to the profane, it can explode suddenly in the spirit, between attacks and convulsions. It can lead to intoxication, to rapture, to ecstasy... in short terms it can become that suspense and humble tremor, in the muteness of the creature before, yes, before whom? before that in the unspeakable mystery looms over all creatures" (Otto, 2007: p. 22).

Mysterium Tremendum, sensitive experience that finds a place in a moment of intimacy in the hierophanic experience, Expression of the total surrender of the human being to the theophany, as the experience of the subjects before the deity, before that one who loves the most, who is most adored, that is more feared, a moment of complete honesty where the total nakedness of the individual before the deity becomes palpable just by seeing their eyes, eyes that reflect love and fear but elevated on an ecstatic level.

In another celebration of Xochitlalli, we were inside a barnyard, kneeling on the ground next to Mrs. Gerónima and Mrs. Soledad, the three of us in front of our Mother Earth, in the space that we had consecrated in the realization of the Xochitlalli. Mrs. Soledad began to pray, bowed her head and with the tenderness with which a newborn is spoken to, but at the same time with the respect with which a wise grandfather speaks and a fear like that one has to a storm that cannot be controlled, she addressed to Mother Earth her apology, her gratitude and her request, which consisted in asking Mother Earth to take care of the hen from an animal that was eating them. As the words came out of her lips, her eyes were bathed in tears, but it was not pain, it was passion, it was tremor and devotion, at that moment Mrs. Soledad was living the Mysterium Tremendum. It is difficult to explain the sensation of the Mysterium Tremendum, since when describing it seems that it is floating in the air, as if it were an experience that is accessed whenever man finds himself in the realm of the divine, when in reality, the experience Hierophany is personal, that although it is possible from a series of collective referents, such as the meaning senses of some objects, what these detonate in 
the body through its representation and the cascade of hormonal secretions unchained, the Mysterium Tremendum is first and foremost a bodily, personal experience that takes place in the realm of sensation in the constant flow of being, but this network of meanings gives meaning to the experience, without the subject reflecting on what they were. felt from the beginning to the vivid hierophanic experience.

The Nahuas from the Sierra de Zongolica have incorporated in their common sense these networks of meanings that have woven around Mother Earth at the moment of feeling the hierophanic experience, thus in the midst of those referents that are the same culture apprehended from the cradle, in that chicken coop between copale smoke, candles, flowers; kneeling in front of the sacred place through the Xochitlalli, it was understood that the observers, the xochitlallera and the applicant understood the earth as a deity that generated life and food, a "Teluric Theophany". Mrs. Soledad and Mrs. Gerónima, had already come forward to request your request, give your thanks and your apology, now it was my turn (Ricardo Alvarez) to speak to Mother Earth, my words to my Mother Earth were honest, I asked her to took care of Mrs. Soledad and her chickens, I spoke very tenderly, with much respect and total surrender of my feelings towards her, at that moment the earth was also my mother because I felt it like that-wise, but my eyes, surely did not reflect the same I could see the shine in Mrs. Soledad and Mrs. Gerónima, they lived the Misterium Tremendum, I approached to it through their experience and I could only observe that feeling from their eyes.

The difference between me and their previous experiences, converted into knowledge and references for the formalization of the phenomena we perceive, because only then they made sense, allows us to recognize that we live and share as members of a society with a complex cultural system in which we have grown and shared referents with the other that integrates them into a we impact in the way we perceive-feel-interpret the phenomenon of Xochitlalli. The culture understood as that network of meanings that the man a fabric, has definitive impacted in the way to feel the same experience

\section{Conclusion}

Human beings throughout time and in all cultures have established guidelines to be able to dialogue between themselves and suprahuman entities. These regulatory guidelines contain in their logic a universe of meanings from which explanations emerge about the construction of the reality of each human group. The Xochitlalli can be observed, from anthropology, as a map that establishes the logics that structure the cosmovision of the Nahua communities from the Sierra de Zongolica in Veracruz, Mexico. These logics make the analysis of the phenomenon more complex, so that an approach from the Systems Theory allows us to go beyond the uni-dimentional explanations: cause and effect, to penetrate into the field of scientific explanations, understood as proposals for generative mechanisms of the phenomenon that it is observed, as a result of its operation. 
The Xochitlalli System is an operational model whose function is to analyze the phenomenon from the coherence of the operations of the elements that give organization to the ritual, which result from the significance that the social actors grant to these, being its main function to establish a dialogue with the deity Mother Earth, from the recognition of certain patterns that allow to delimit the asymmetric relationship that exists between the common man and the magnificent deity on which the Nahuas of Zongolica depend to survive, Mother Earth.

We propose the Xochitlalli System, as a way to interpret this ritual practice and because of the enormous variety of presentations, forms, colors and contexts in the Zongolica mountain range, which has led the researchers who have treated the subject, to create a cataloging of Xochitlalli as: Xochitlalli for healing, Xochitlalli for birth, Xochitlalli for harvest, etc., as if it each was different and in the practice of ritual is not like that, the Xochitlalli ritual is always the same and fulfills the same function: to establish the necessary guidelines for a dialogue with the Mother Earth in the terms that she, as a majestic being, requires. This could be made evident by recognizing, in the Xochitlalli observed during the field work, a series of elements that give organization to the phenomenon, so they are always present in each ceremony, because their symbolism is essential to establish the terms necessary for communication with Mother Earth.

The 3 fundamental elements that make up the Xochitlalli System are: 1) Food (Coffee, Aguardiente, Beer); 2) Ritual Objects (Waxes, Cross cover with flowers, Xochimanale "Bouquet of flowers"), Incense, Flower Petals, Tobacco. 3) Prayers in Nahuatl.

The discursive logic that allows to interrelate food, prayers and ritual objects, which explains the fact of its constant and obligatory presence in all Xochitlalli, is deduced from the interviews made with xochitlaleras, midwives, applicants of Xochitlalli and inhabitants of Zongolica in general, it was also translated from the prayers made in Nahua and translated into Spanish of the Xochitlalli ceremonies as well as observing the daily behavior of the population; and the way of relating among the Nahuas of Zongolica and with the Mother Earth entity, through: asking for forgiveness, asking for permission and thanking. The conceptual triad: ask for forgiveness, ask permission and thank; is present both in the prayers and requests made at the time of the Xochitlalli, and in the acts from the forms of interaction with the entity the Mother Earth, in the tenderness of the voice when praying, the cleanliness with which he prepares the food prepared by a single person and that no one can touch, the tears that flow with complete honesty at the moment of prayer.

No matter the motive, reason, place, request, context or the xochitlalera, permission is always requested, forgiveness and grattitude. The fact that the relationship with Mother Earth is in these terms has to do with an intention of respect, admiration, fear and hope, communication that cannot be otherwise in front of the omnipotence and omnipresence of Mother Earth, understood as a deity for the Nahuas from the Sierra de Zongolica. The anthropological reflection of this ritual system leads us to observe how the Nahua from the Sierra de 
Zongolica is articulated to its cultural system since childhood receiving certain cultural codes with which it constructs its referents of collective identity from which it is explained the phenomena that it perceives. The integration of the Nahua from Zongolica to its cultural system from their experiences, understood as knowledge that is acquired in everyday life, is what enables the manifestation of this type of relationship based on respect, fear and admiration that builds the Nahua de Zongolica regarding his relationship with Mother Earth.

The subject is vast and this article does not delve deeply into details and very particular phenomena of this practice and we consider that to broaden the understanding of this ritual system, we must investigate further the root symbology of "the flowers", not only as an object but as a metaphor that comes from referents inherited from the pre-Hispanic era of Mexico. It should also deepen the role of ritual objects themselves and how their symbolic value is transformed from entering and leaving different spaces subject to different value regimes.

\section{Conflicts of Interest}

The authors declare no conflicts of interest regarding the publication of this paper.

\section{References}

Alvarez, L. N. E. (2012). Estigma, prejuicio e identidad en la práctica del tatuaje, un modelo de análisis para su estudio. México: Instituto Politécnico Nacional.

CONEVAL (2015). Veracruz 2010-2015. Coneval medición de la pobreza. https://www.coneval.org.mx/coordinacion/entidades/Veracruz/Paginas/pobreza_muni cipal2015.aspx

De la Reza, G. (2010). Sistemas complejos. Perspectivas de una teoría general. México: Universidad Autónoma Metropolitana, ANTHROPOS.

Di Castro, E. (2002). La razón desencantada. Un acercamiento a la teoría de la elección racional. México: UNAM, Instituto de Investigaciones Filosóficas.

Dumont, L. (1987). Ensayos sobre el individualismo. Madrid: Alianza universidad.

Eliade, M. (1991). Mitos sueños y misterios. Madrid: Editorial GL, Colección Paraísos Perdidos.

Eliade, M. (2008). El mito de eterno retorno. Buenos Aires: Editorial: Alianza/Emecé.

Geertz, C. (1994). Conocimiento Local. Barcelona: Paidós.

INEGI (2013). Image Taken from the National Institute of Statistics and Geography. México.

Lévi-Strauss, C. (1992). Antropología Estructura. Barcelona: Paidós.

Maturana, R. H. (2014). Transformación en la convivencia. Chile: J.C.SÁES Editor, Ediciones GARNICA.

Otto, R. (2007). Lo santo. Lo racional e irracional en la idea de dios. Madrid: Alianza Editorial.

Pérez Argote, A. (1986). La identidad colectiva: Una reflexión abierta desde la sociología. Revista de Occidente, No. 56, 76-90. 